\title{
ANALISIS DAMPAK DELAY YANG TERJADI PADA RUNWAY, APRON DAN RUANG UDARA TERHADAP OPERASIONAL PESAWAT (STUDI KASUS: BANDARA INTERNASIONAL JUANDA)
}

\author{
Laila Fatchiyaha dan Ervina Ahyudanarib
}

\begin{abstract}
The Air transport demand still increasing continuously both of number passengers, cargo and aircraft movements will have a direct impact on the capacity of the airport. Juanda International Airport has one runway that serves about 35-40 aircraft per hour. The number of aircraft movements cause the problem of delay and wasting fuel. Delay can reduced the productivity airport services and airlines. This goal of this paper is to analyze the airport capacity, delay and effect of delay on the aircraft's fuel consumption. Calculations using simulation software arena with arrivals and departure modelling. The results showed that in the calculation of the existing runway capacity as much as 44 scheduled aircraft movements during peak hours there are only 33 aircraft for 1 hour with an average delay of 29 minutes. Simulations using the software arena, delay for arrival varied between 0.6 minutes to 4.2 minutes and delay for departure varied between 0.8 minutes to 19 minutes. Aircraft fuel consumption A320 for the queue 1 to 4 of aircraft varied between $67.56 \mathrm{lb}$ to $270.26 \mathrm{lb}$. While fuel consumption B737-500 for the queue 1 to 4 of aircraft varied between $131.31 \mathrm{lb}$ to $525.26 \mathrm{lb}$.
\end{abstract}

Keywords: airside, runway capacity, flight delay, simulation

\begin{abstract}
Abstrak: Permintaan transportasi udara yang terus meningkat baik dari segi jumlah penumpang, barang dan pergerakan pesawat akan berdampak langsung pada kemampuan kapasitas bandara. Bandara Internasional Juanda memiliki satu runway yang melayani sekitar 35-40 pesawat/jam. Banyaknya pergerakan pesawat menjadi salah satu penyebab delay dan pemborosan bahan bakar pesawat. Delay mengakibatkan menurunnya produktivitas pelayanan bandara dan maskapai pesawat. Paper ini bertujuan untuk menganalisis kapasitas bandara, delay di sisi udara bandara dan pengaruh delay terhadap konsumsi bahan bakar pesawat. Metode perhitungan menggunakan simulasi software ARENA dengan memodelkan kedatangan dan keberangkatan pesawat. Hasil analisis menunjukkan bahwa 44 pergerakan pesawat terjadwal pada saat peak hour hanya terdapat 33 pesawat selama 1 jam dengan rata-rata delay 29 menit. Hasil simulasi menunjukkan delay yang terjadi untuk kedatangan pesawat bervariasi menit dari 0,6 menit sampai 4,2 menit dan delay yang terjadi untuk keberangkatan bervariasi dari 0,8 menit hingga 19 menit. Konsumsi bahan bakar A320 untuk antrian 1 sampai 4 pesawat bervariasi antara 67,56 lb hingga 270,26 lb. Sedangkan konsumsi bahan bakar B737-500 untuk antrian 1 sampai 4 pesawat bervariasi antara 131,31 lb hingga $525,26 \mathrm{lb}$.
\end{abstract}

Kata kunci: sisi udara, kapasitas runway, delay penerbangan, simulasi

\section{PENDAHULUAN}

Transportasi udara kian diminati masyarakat karena memiliki berbagai keunggulan yakni cepat, aman dan efisien. Hal ini menjadi penyebab terus meningkatnya permintaan transportasi udara. Pergerakan pesawat yang terus meningkat akan berdampak langsung pada kemampuan kapasitas bandara dalam melayani permintaan lalu lintas udara. Kapasitas merupakan ukuran penting keefektifan suatu bandara. Kapasitas bandara dianggap sebagai jumlah operasi pesawat terbang maksimum yang dapat ditampung oleh fasilitas bandara dalam satuan waktu (Horonjeff, dkk, 2010). Perhitungan kapasitas bandara bertujuan untuk menjelaskan kapasitas dari suatu bandara sebagai dasar pengembangan bandara di masa mendatang dalam menghadapi pertumbuhan lalu lintas udara. Perhitungan kapasitas bandara telah

astudent in the Department of Civil Engineering, Sepuluh Nopember Institute of Technology (ITS), ITS Campus, Sukolilo, Surabaya 60111, Indonesia. Email: Laila.fatchiyah10@ gmail.com

${ }^{b}$ Lecturer in the Department of Civil Engineering, Sepuluh Nopember Institute of Technology (ITS), ITS Campus, Sukolilo, Surabaya 60111, Indonesia. Email: ervinaa.ariatedja@gmail.com

Note. The manuscript for this paper was submitted for review and possible publication on January 19, 2017. This paper is part of the ITS Journal of Civil Engineering, Vol. 31, No. 2, November 2017. (C) ITS Journal of Civil Engineering, ISSN 2579-9029/2017. disediakan oleh Federal aviation administration (FAA) Advisory Circular (AC) 150/5060-5.

Banyak penelitian yang dilakukan mengenai kapasitas bandara dan faktor-faktor yang mempengaruhinya. Permintaan industri transportasi udara berdampak pada keterbatasan kapasitas bandara dalam jaringan transportasi udara global. Hasil analisis dari 177 sampel bandara (dengan total sekitar 2400 bandara seluruh dunia) diperkiraan pada tahun 2016 apabila tidak ada penambahan kapasitas, maka $70 \%$ penerbangan akan dibatasi (Gelhausen, dkk, 2013).

Faktor-faktor yang mempengaruhi kapasitas suatu bandara adalah komponen-komponen utama di dalam bandara yakni sisi udara dan sisi darat. Dalam kaitannya dengan pergerakan pesawat, sisi udara berperan penting penting untuk menunjang terciptanya jaminan keselamatan, keamanan dan kelancaran penerbangan yang dilayani. Pergerakan pesawat di sisi udara erat kaitannya dengan take off dan landing. Terbatasnya kapasitas mengakibatkan pesawat harus mengantri di darat untuk take off dan berputar-putar di udara untuk landing.

Permasalahan keterbatasan kapasitas yang mengakibatkan antrian berdampak pada pemborosan bahan bakar pesawat (avtur) dan penjadwalan pesawat yang tidak optimal yang mengakibatkan penundaan (delay). Penelitian yang pernah dilakukan menyebutkan 


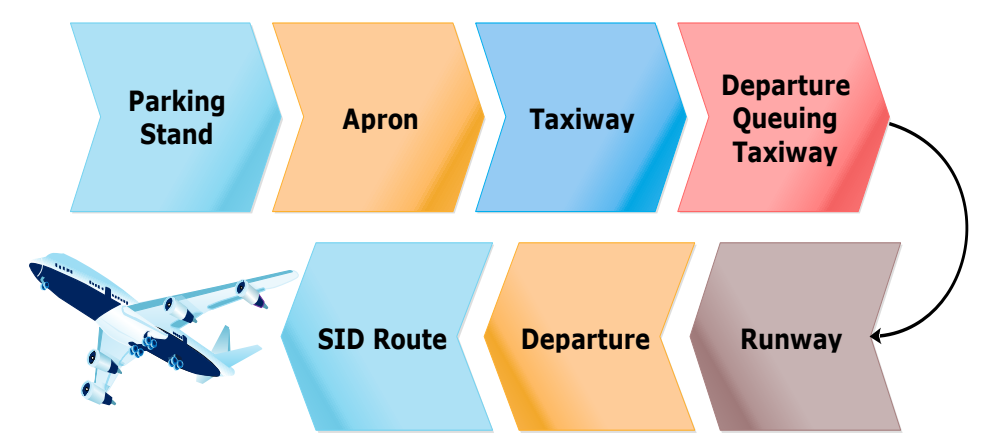

Gambar 1. Fase keberangkatan pesawat

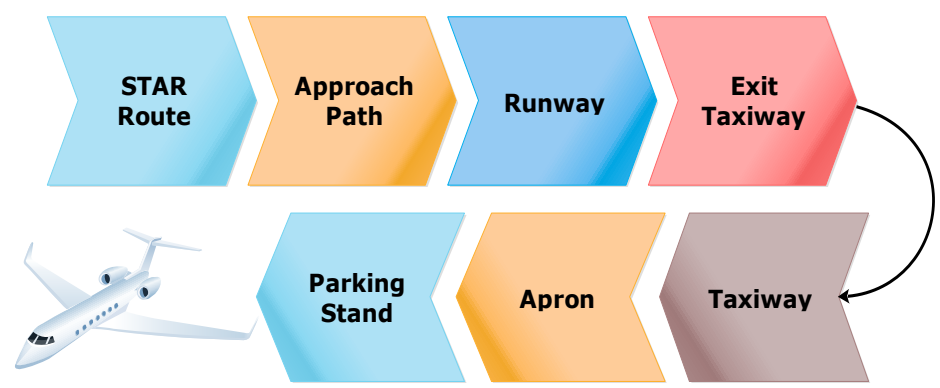

Gambar 2. Fase kedatangan pesawat

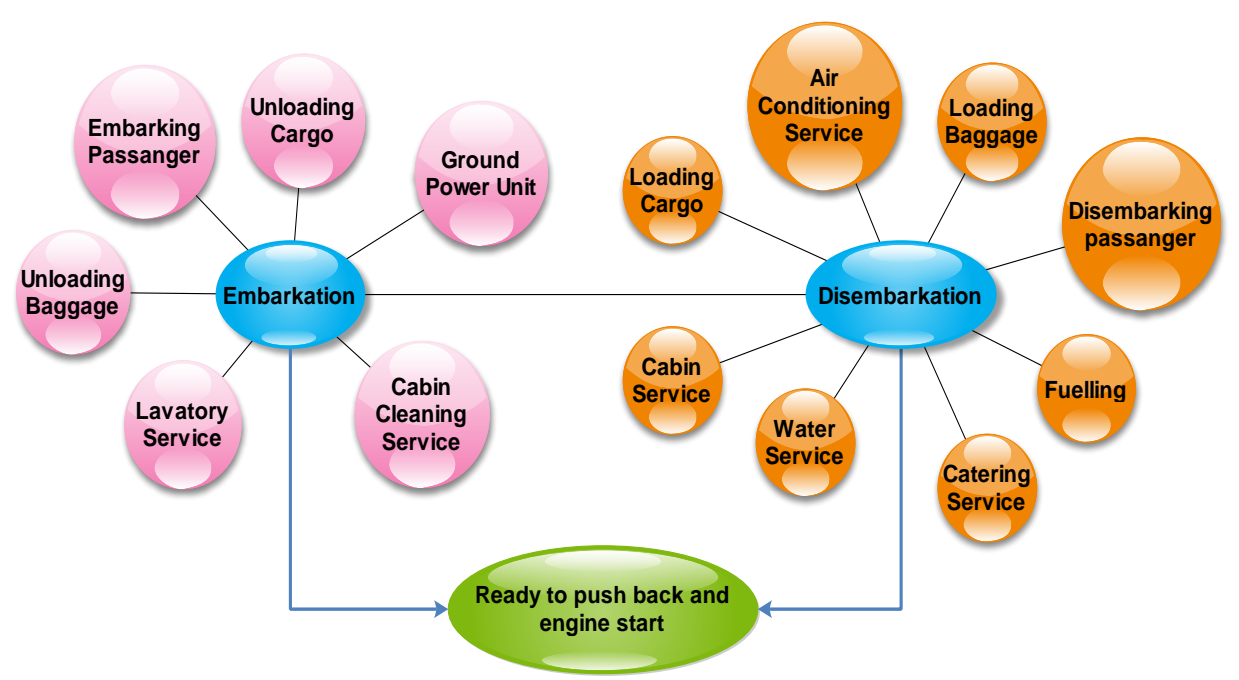

Gambar 3. Proses groundhandling

bahwa pengurangan konsumsi bahan bakar dapat melalui pengurangan delay dan peningkatan efisiensi daerah terminal (Ryerson, 2014).

Delay menjadi masalah konktrit yang terjadi di industri penerbangan. Menurut Biro Statistik Transportasi US penyebab terjadinya delay pesawat didefinisikan menjadi beberapa kategori yakni dari pihak maskapai, keadaan cuaca, National Aviation System (NAS), dan keterlambatan kedatangan pesawat dari bandara asal. Permasalahan delay menimbulkan kerugian yang besar. Dampak dari adanya delay tidak hanya merugikan satu pihak saja, melainkan beberapa pihak yang terkait. Delay tentunya merugikan penumpang, pihak maskapai, bahkan sampai dengan kru pesawat yang bertugas.

Berdasarkan uraian diatas, permasalahan mengenai keterbatasan kapasitas bandara dan delay dapat dipastikan bahwa kedua hal tersebut mengakibatkan menurunnya produktivitas pelayanan bandara dan maskapai pesawat. Oleh karena itu, melalui paper ini diharapkan mengetahui pengaruh kapasitas bandara, delay yang terjadi di sisi udara dan pengaruh delay terhadap konsumsi bahan bakar pesawat. Metode perhitungan menggunakan simulasi software ARENA dengan memodelkan kedatangan pesawat dari STAR (Standard Arrival Route) yang merupakan rute standar pesawat ketika akan mendarat hingga pesawat landing dan menempati parking stand. Pemodelan simulasi juga untuk keberangkatan pesawat dari parking stand apron menuju runway hingga pesawat take off.

\section{PERGERAKAN PESAWAT}

Pergerakan pesawat di sisi udara bandara berkaitan dengan kapasitas masing-masing komponen sisi udara. Pergerakan pesawat terbagi menjadi tiga bagian yakni keberangkatan pesawat, kedatangan pesawat dan ground handling, seperti pada Gambar 1, Gambar 2, dan Gambar 3.

Secara umum proses ground handling terbagi menjadi dua yakni embarkation dan disembarkation seperti pada Gambar 3. 
Masing-masing fase pergerakan pesawat di sisi udara memiliki peran menjaga keefektifan setiap proses. Karena apabila terjadi delay terhadap salah satu proses, maka akan memberikan efek domino terhadap proses yang lain.

\section{KAPASITAS BANDARA}

Kapasitas bandara dipengaruhi oleh variasi pesawat yang beroperasi (mix of aircraft), aturan penerbangan (flight rules) yang diterapkan yakni visual atau instrument, alat navigasi yang digunakan di bandara, konfigurasi penggunaan runway dan system taxiway. Komponen yang mempengaruhi kapasitas bandara sebagai berikut:

\section{Kapasitas Runway}

Kapasitas runway adalah maksimum pergerakan pesawat secara berkelanjutan, baik kedatangan maupun keberangkatan, yang dapat diselenggarakan pada periode waktu tertentu pada konfigurasi runway yang ditentukan, pada kondisi cuaca tertentu dan tundaan yang bisa diterima (Ashford, dkk, 2011).

Salah satu elemen yang penting dalam mengoptimalkan kapasitas runway yakni mengurangi waktu yang dihabiskan oleh pesawat saat di runway. Waktu yang dibutuhkan pesawat ketika berada di runway disebut ROT (Runway Occupancy Time). Runway Occupancy Time (ROT) adalah waktu yang dibutuhkan pesawat ketika berada di runway.

Setiap jenis pesawat memiliki karakter masing-masing ketika menggunakan runway. Faktor yang mempengaruhi ROT bukan hanya jenis pesawat saja melainkan speed exit taxiway. Apabila suatu runway dilengkapi fasilitas high speed exit taxiway maka angka ROT semakin kecil, hal ini dikarekan setelah pesawat mendarat, pesawat dapat dengan cepat keluar dari daerah runway.

\section{Sistem Taxiway}

Taxiway merupakan fasilitas penghubung dari runway menuju apron. Ashford, dkk (2011) menjelasakan bahwa kunci dalam tata letak bandara adalah sistem taxiway, yang menghubungkan runway ke terminal daerah gate apron dan layanan pesawat hanggar. Berdasarkan letaknya taxiway terbagi atas entrance taxiway dan exit taxiway. Kapasitas dari komponen taxiway perlu diperhitungkan apabila terdapat taxiway yang memotong runway, karena akan berpengaruh pada operasi kapasitas runway.

Exit taxiway merupakan komponen taxiway yang berfungsi untuk memperpendek masa penggunaan runway pada saat pendaratan pesawat di runway. Exit taxiway disebut sebagai high speed taxiway jika sudut beloknya sekitar $30^{\circ}-45^{\circ}$. Jumlah exit taxiway direncanakan mampu mengakomodasi lalu lintas pergerakan pesawat pada jam puncak.

\section{Kapasitas Apron}

Apron merupakan fasilitas sisi udara yang disediakan sebagai tempat bagi pesawat saat melakukan kegiatan menaikkan dan menurunkan penumpang, muatan pos dan kargo dari pesawat, pengisian bahan bakar, parkir dan perawatan pesawat. Kebutuhan dan ukuran apron sebaiknya diperkirakan berdasarkan pada tipe dan ramalan volume lalu lintas pada suatu bandara.
Fasilitas apron juga dipengaruhi oleh kapasitas gate apron. Kapasitas gate merupakan kemampuan dari sejumlah gate tertentu untuk mengakomodasi proses bongkar muat pesawat dalam kondisi permintaan yang terus menerus. Jumlah maksimum pesawat yang pengoperasiannya dapat diakomodasi oleh komponen grup gate apron (gate capacity) bergantung pada:

1. Komposisi parkir pesawat pada gate-apron

2. Pelayanan dasar pesawat dan karakteristik pemuatan penumpang

3. Jumlah dan gabungan dari gate dan area berdasarkan kategori

4. Pelaksanaan penjadwalan pesawat

Waktu pemakaian gate (gate occupancy time) bergantung pada ukuran pesawat dan tipe operasi penerbangan di suatu bandara. Untuk pesawat transfer mungkin hanya memerlukan waktu 20 - 30 menit parkir karena hanya memerlukan sedikit pelayanan. Sedangkan untuk pesawat dengan turn around flight memerlukan pelayanan keseluruhan sehingga memerlukan waktu parkir selama 40 menit sampai lebih dari 1 jam.

\section{DELAY}

Delay penerbangan adalah terjadinya perbedaan waktu antara keberangkatan atau kedatangan yang dijadwalkan dengan realisasi waktu keberangkatan atau kedatangan. Delay penerbangan bisa terjadi untuk rentang waktu 1 jam mundur atau lebih.

Menurut Biro Statistik Transportasi US penyebab terjadinya penundaan keberangakatan pesawat didefinisikan menjadi beberapa kategori

Maskapai penerbangan, hal ini menyangkut permasalahan perawatan, pembersihan pesawat, proses menaikkan penumpang, bongkar muat bagasi, pengisian bahan bakar, dan lain-lain.

$>$ Keadaan cuaca, seperti cuaca buruk, hujan lebat, badai salju, petir, dan sebagainya.

$>\quad$ National Aviation System (NAS) yang mengacu pada serangkaian kondisi yang lebih luas, seperti operasional bandara, volume lalu lintas yang tinggi, dan juga Air Traffic Control (ATC).

$>$ Keterlambatan kedatangan pesawat, keterlambatan pesawat dari bandara asal menyebabkan pesawat selanjutnya mengalami penundaan.

$>$ Permasalahan keamanan, penundaan atau pembatalan penerbangan dapat disebabkan oleh evakuasi dari terminal, re-boarding pesawat karena pelanggaran keamanan, peralatan screening yang bermasalah atau adanya antrian lebih dari 29 menit pada daerah screening.

Peraturan Menteri Perhubungan Nomor PM 89 Tahun 2015, membagi keterlambatan penerbangan menjadi 3 jenis yaitu :

1. keterlambatan penerbangan (flight delayed);

2. tidak terangkutnya penumpang dengan alasan kapasitas pesawat udara (denied boarding passenger);

3. pembatalan penerbangan (cancelation of flight). 


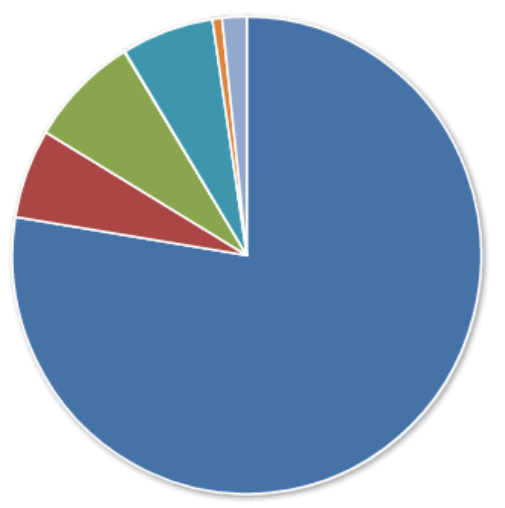

On Time: $77.57 \%$

Air Carrier Delay: $6.04 \%$

Aircraft Arriving Late : $7.65 \%$

Security Delay: 0.04\%

National Aviation System Delay: $6.35 \%$

Extreme Weather: $0.67 \%$

Cancelled \& Diverted: $1.68 \%$

Gambar 4. Prosentase penyebab delay penerbangan

Sumber: The U.S. Department of Transportation's (DOT) Bureau of Transportation Statistics (BTS)

Dalam pasal selanjutnya keterlambatan penerbangan dikelompokkan menjadi 6 (enam) kategori keterlambatan, yaitu:

$>$ Kategori 1, keterlambatan 30 menit s/d 60 menit; kompensasi berupa minuman ringan

$>$ Kategori 2, keterlambatan 61 menit s/d 120 menit; kompensasi berupa minuman dan makanan ringan (snack box)

$>$ Kategori 3, keterlambatan 121 menit s/d 180 menit; kompensasi berupa minuman dan makanan berat (heavy meal)

$>$ Kategori 4, keterlambatan 181 menit s/d 240 menit; kompensasi berupa minuman, makanan ringan (snack box), makanan berat (heavy meal)

$>$ Kategori 5, keterlambatan lebih dari 240 menit; kompensasi berupa uang ganti rugi Rp. 300.000,00 (tiga ratus ribu rupiah)

$>$ Kategori 6, pembatalan penerbangan; badan usaha angkutan udara wajib mengalihkan ke penerbangan berikutnya atau mengembalikan seluruh biaya tiket (refund ticket)

Delay menyebabkan kerugian yang dialami oleh para penumpang, maskapai sampai pihak kru yang bertugas. Diantara kerugiannya adalah terkait dengan biaya dan waktu yang dikeluarkan oleh penumpang, maskapai serta kru yang bertugas. Estimasi biaya yang dikeluarkan maskapai akibat delay akan cenderung meningkat ketika ada perubahan dalam biaya bahan bakar, jenis pesawat, atau ketika beberapa biaya lain mungkin ditambahkan ke dalam struktur biaya keseluruhan (Ferguson, dkk, 2011).

Keuntungan yang signifikan dalam efisiensi transportasi udara dapat diwujudkan melalui pemahaman tentang faktor-faktor yang menyebabkan keterlambatan dan dengan penerapan inovasi teknologi dan kebijakan operasional untuk mengurangi delay. (Horenjeff $\mathrm{dkk}$, 2010).

\section{METODOLOGI}

Analisis kapasitas bandara dan delay dapat menggunakan pendekatan simulasi. Simulasi merupakan suatu model pengambilan keputusan dengan mencontoh atau mempergunakan gambaran sebenarnya dari suatu sistem kehidupan dunia nyata tanpa harus mengalaminya pada keadaan yang sesungguhnya (Hasan, 2002). Simulasi memiliki beberapa kelebihan, diantaranya :
1. Simulasi mampu menggambarkan suatu prosedur operasional untuk rentang waktu yang lebih singkat dari perencanaan.

2. Simulasi mampu menyajikan sistem nyata yang lebih besar dan rumit atau kompleks, dibandingkan dengan model matematika yang masih konvensional.

3. Dengan simulasi, penggunanya dapat menjadikan hasil simulasi sebagai pengambilan keputusan misalnya untuk penerapan sistem maupun memutuskan langkah-langkah prefentif aspek lainnya. Penelitian ini menggunakan bantuan pemodelan simulasi dengan software ARENA yang dapat digunakan untuk membangun model kontinyu ataupun diskrit (Kelton, dkk, 2003). Model simulasi di ARENA dibangun secara mudah dengan bantuan modul-modul grafis. Selain itu, ARENA juga menyediakan model animasi dua dimensi. Dengan kemampuan animasi maka proses debugging dan verifikasi model akan lebih mudah. Reperesentasi model secara visual akan membantu pemahaman sistem secara utuh sehingga analisis dan pengambilan keputusan akan lebih efektif.

Model konseptual dari sebuah proses kedatangan pesawat dan keberangkatan pesawat dideskripsikan dengan diagram alur yang selanjutnya dibangun dalam ARENA. Dalam arena dibuat perancangan model simulasi yaitu membuat kondisi sistem dari delay yang terjadi sebenarnya di Bandara Internasional Juanda.

Tujuan simulasi tersebut untuk menggambarkan sistem secara nyata dan terperinci dari keadaan delay yang terjadi. Dari simulasi yang dilakukan dapat diketahui delay pada masing-masing komponen sisi udara. Beberapa teori simulasi telah diterapkan dalam penelitian mengenai kapasitas bandara. Antony Evansn dan Andreas W. Schäfer (2014) melakukan simulasi dengan memprediksi respon operasional maskapai terhadap keterbatasan kapasitas bandara.

Simulasi juga diterapkan untuk permasalahan delay. Penelitian yang pernah dilakukan yakni menggunakan metode simulated annealing algorithm menunjukkan bahwa model yang dibangun dapat mengurangi biaya dan pengaruh delay sebanyak mungkin (Tian Jungai dan $\mathrm{Xu}$ Hongjun, 2012). Penelitian yang dilakukan Larasati (2013) dengan mensimulasikan pergerakan pesawat dapat melihat perubahan jadwal yang disebabkan oleh delay berakibat pada penundaan penerbangan lain. Meminimumkan permasalahan delay juga dapat menggunakan program matematis linier integer 


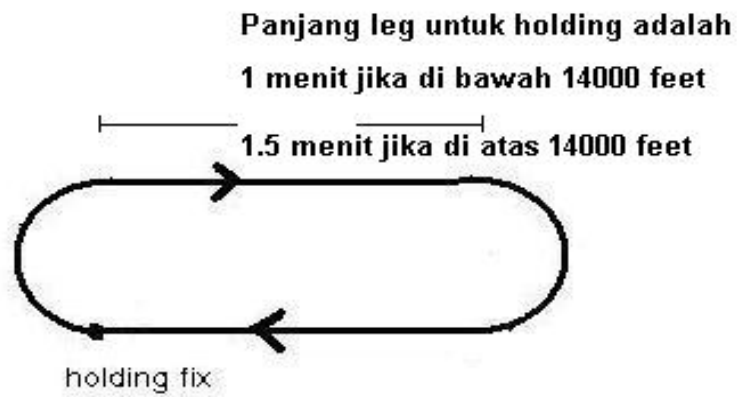

Gambar 5. Holding Pattern

http://www.ilmuterbang.com

Tabel 1. Perhitungan delay di ruang udara

\begin{tabular}{|c|c|c|c|c|c|}
\hline $\begin{array}{c}\text { Jadwal } \\
\text { Kedatangan }\end{array}$ & $\begin{array}{c}\text { Jenis } \\
\text { Pesawat }\end{array}$ & $\begin{array}{c}\text { Kategori } \\
\text { Pesawat }\end{array}$ & $\begin{array}{c}\text { Separasi } \\
\text { (detik) }\end{array}$ & $\begin{array}{c}\text { Waktu } \\
\text { approach }\end{array}$ & $\begin{array}{c}\text { Selisih } \\
\text { waktu }\end{array}$ \\
\hline $17: 30$ & B737-900 & D & & $17: 28: 15$ & \\
\hline $17: 30$ & A330 & C & 75 & $17: 28: 55$ & $0: 00: 40$ \\
\hline $17: 30$ & A330 & C & 47 & $17: 30: 10$ & $0: 01: 55$ \\
\hline $17: 30$ & A330 & C & 47 & $17: 30: 57$ & $0: 02: 42$ \\
\hline $17: 30$ & A330 & C & 47 & $17: 31: 44$ & $0: 03: 29$ \\
\hline
\end{tabular}

progranmming dengan rescheduling flight untuk meminimumkan biaya crew, dan pembatalan penerbangan (Brunner, 2014).

\section{ANALISIS KAPASITAS RUNWAY DAN DELAY}

Analisis kapasitas bandara berdasarkan data eksisting menggunakan time space diagram. Perhitungan kapasitas eksisting bandara terdapat 44 pergerakan pesawat terjadwal saat peak hour, akan tetapi hanya 33 pesawat yang dapat dilayani bandara selama 1 jam. Berdasarkan hal tersebut terjadi delay dengan rata-rata 29 menit. Delay ini didapat dari selisih antara jadwal penerbangan dengan jadwal actual di bandara. Terjadinya delay tersebut tentunya bervariasi. Apabila dilihat dari status arrival dan terdapat delay, maka delay disebabkan dari bandara asal. Delay dari bandara asal terjadi dari range 10 menit hingga 3 jam. Penyebab delay yang lain yakni akibat aktivitas sisi udara bandara.

Berdasarkan data eksisting terdapat lima kedatangan pesawat secara bersamaan. Hal tersebut mengindikasikan bahwa terdapat pesawat yang antri di holding area karena tidak dapat melakukann landing. Holding area merupakan area di ruang udara yang ditujukan untuk menunda pesawat yang telah tiba di bandara akan tetapi tidak dapat mendarat karena beberapa permasalahan. Pada saat pesawat berada di holding area dalam sekali putaran pesawat membutuhkan waktu selama 1 menit (lihat gambar 5).

Delay di holding area dapat dilakukan analisis dengan menarik waktu dari pesawat approach kemudian dihitung selisih waktu untuk pesawat berikutnya. Selisih waktu tersebut menunjukkan bahwa pesawat mengalami delay (lihat Tabel 1).

Apabila pesawat yang akan mendarat berada pada ketinggian $2500 \mathrm{ft}$, maka pesawat berikutnya selisih 1000 ft. Setiap pesawat di pisahkan oleh jarak vertical $1000 \mathrm{ft}$ dan jarak horizontal yakni separasi minimum untuk arrivalarrival

Untuk mengetahui pergerakan pesawat secara random dan besarnya delay dilakukan simulasi menggunakan software ARENA. Simulasi pergerakan pesawat dalam bandara terbagi menjadi 2 bagian. Simulasi untuk kedatangan pesawat dimulai dari STAR (Standard Arrival Route) menuju runway hingga pesawat menempati parking stand. Simulasi untuk keberangkatan pesawat dimulai dari pesawat terparkir di apron kemudian taxiing menuju runway hingga pesawat take off.

Dalam simulasi untuk mengetahui sistem pergerakan pesawat dilakukan simulasi random number berdasarkan komposisi pesawat eksisting dan simulasi random number berdasarkan variasi komposisi. Variasi komposisi dilakukan dengan merubah prosentase komposisi jenis pesawat, banyaknya kedatangan pesawat dan prosentase pesawat yang menggunakan parking stand.

Delay terbersar diperoleh dari komposisi pesawat B sebesar $5 \%$, pesawat $\mathrm{C}$ sebesar $70 \%$ dan pesawat D sebesar $25 \%$ dengan pengisian slot parkir pesawat sebesar 50\% dan nilai batch untuk kedatangan $(1,10)$ sedangkan untuk keberangkatan $(1,2)$. Nilai batch ini menunjukkan tingkat kedatangan dan keberangkatan pesawat dengan jam yang sama adalah random dari 1 sampai 10 dan 1 sampai 2 untuk keberangkatan. Delay di holding apron dapat dilihat yakni rata-rata delay sebesar 9,2 menit. Sedangkan delay maksimum yang terjadi adalah 19,3 menit.

\section{PENGARUH DELAY TERHADAP KONSUMSI BAHAN BAKAR PESAWAT}

Perhitungan konsumsi bahan bakar dilakukan pada dua jenis pesawat yang beroperasi di Bandara Internasional 

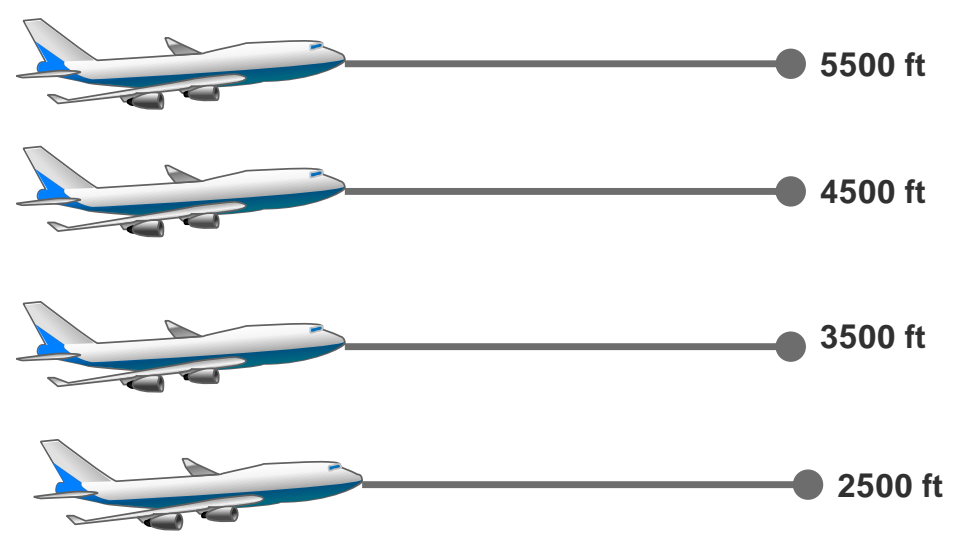

Gambar 6. Posisi pesawat pada holding area

Tabel 2. Konsumsi bahan bakar A320 di holding area

\begin{tabular}{|c|c|c|c|c|}
\hline $\begin{array}{c}\text { Jenis } \\
\text { Pesawat }\end{array}$ & Engine & $\begin{array}{c}\text { Fuel } \\
\text { Consumption } \\
\text { (lb/h) }\end{array}$ & $\begin{array}{c}\text { Putaran } \\
\text { (menit) }\end{array}$ & $\begin{array}{c}\text { Konsumsi Bahan } \\
\text { Bakar Saat Delay (lb) }\end{array}$ \\
\hline A320 & CFM56-5A3 & 4054 & 1 & 67.56667 \\
\hline A320 & CFM56-5A4 & 4054 & 2 & 135.13333 \\
\hline A320 & CFM56-5A5 & 4054 & 3 & 202.70000 \\
\hline A320 & CFM56-5A6 & 4054 & 4 & 270.26667 \\
\hline
\end{tabular}

Tabel 3. Konsumsi bahan bakar B737-500 di holding area

\begin{tabular}{|c|c|c|c|c|}
\hline $\begin{array}{c}\text { Jenis } \\
\text { Pesawat }\end{array}$ & Engine & $\begin{array}{c}\text { Fuel } \\
\text { Consumption } \\
\text { (lb/h) }\end{array}$ & $\begin{array}{c}\text { Putaran } \\
\text { (menit) }\end{array}$ & $\begin{array}{c}\text { Konsumsi Bahan } \\
\text { Bakar Saat Delay (lb) }\end{array}$ \\
\hline B-737-500 & FM56-3B1R & 7879 & 1 & 131.31667 \\
\hline B-737-500 & FM56-3B1R & 7879 & 2 & 262.63333 \\
\hline B-737-500 & FM56-3B1R & 7879 & 3 & 393.95000 \\
\hline B-737-500 & FM56-3B1R & 7879 & 4 & 525.26667 \\
\hline
\end{tabular}

Juanda. Pengaruh delay terhadap konsumsi bahan bakar dapat dilakukan apabila diketahui terjadi antrian pesawat saat di holding area. Perhitungan konsumsi bahan bakar mengacu pada buku "Planning and Design of Airports" (horenjeff dkk, 2010) untuk pesawat A320 konsumsi bahan bakar per jam adalah $4054 \mathrm{lb}$. Berikut adalah perhitungan konsumsi bahan bakar untuk masing-masing antrian pesawat.

Pada tabel 2 diketahui perhitungan konsumsi bahan bakar selama 1 putaran sampai 4 putaran di holding area. Mengacu pada teori bahwa dalam 1 kali putaran di holding area dengan ketinggian dibawah $14000 \mathrm{ft}$ membutuhkan waktu 1 menit. Berdasarkan perhitungan persamaan yang diperoleh adalah $y=67,567 x+2 E-13$. Persamaan tersebut dapat digunakan apabila terjadi antrian lebih dari 4 pesawat.

Sama halnya dengan pesawat jenis Airbus, untuk Boeing juga dilakukan perhitungan konsumsi bahan bakar akibat delay. Konsumsi bahan bakar B737-500 adalah 7879 lb/jam, perhitungan dilakukan dengan mengetahui banyaknya antrian pesawat saat di holding area. Berikut adalah perhitungan konsumsi bahan bakar untuk masingmasing antrian pesawat B737-500.

Perhitungan pada tabel 3 merupakan perhitungan konsumsi bahan bakar pesawat selama melakukan 1 putaran hingga 4 putaran di holding area. Hasil perhitungan diperoleh persamaan $\mathrm{y}=131,32 \mathrm{x}+4 \mathrm{E}-13$.

\section{KESIMPULAN}

1. Hasil menunjukkan bahwa pada perhitungan kapasitas eksisting runway sebanyak 44 pergerakan pesawat terjadwal pada saat peak hour hanya terdapat 33 pesawat yang dilayani selama 1 jam dengan rata-rata delay 29 menit.

2. Memodelkan simulasi kedatangan pesawat dan keberangkatan pesawat menunjukkan delay yang terjadi untuk kedatangan pesawat bervariasi menit dari 0,6 menit sampai 4,2 menit dan delay yang terjadi untuk keberangkatan bervariasi dari 0,8 menit hingga 19 menit.

3. Konsumsi bahan bakar A320 untuk antrian 1 sampai 4 pesawat bervariasi antara 67,56 lb hingga 270,26 lb. Sedangkan konsumsi bahan bakar B737-500 untuk antrian 1 sampai 4 pesawat bervariasi antara $131,31 \mathrm{lb}$ hingga 525,26 lb.

\section{DAFTAR PUSTAKA}

[1] Ashford, N.J., (2011), Airport Engineering planning, design, and development of 21 st century airports, 
Fourth Edition, United State of America, John Wiley and Sons, Inc.

[2] Berau of transport Statistic, (2014). Airline on-time and delay causes.

[3] Brunner J.O. (2014). "Rescheduling of flights during ground delay programs with consideration of passenger and crew connections", Journal of Transportation Research Part E, Vol. 72, hal. 236252.

[4] Direktorat Jenderal Perhubungan Udara. (2015). Peraturan Menteri Perhubungan Republik Indonesia Nomor PM 89 Tahun 2015 tentang Penanganan Keterlambatan Penerbangan (Delay Management) Pada Badan Usaha Angkutan Udara Niaga Berjadwal Di Indonesia.

[5] Evans A., \& Schäfer A.W. (2014), “ Simulating airline operational responses to airport capacity constraints", Journal of Transport Policy, Vol. 34, hal. 5-1.

[6] Gelhausen, M.C., Berster, P., Wilken, D., (2013), "Do airport capacity constraints have a serious impact on the future development of air traffic?", Journal of Transport Management, Vol. 28, hal. 3-13.

[7] Federal aviation administration (FAA), 2007. Airport capacity and delay.

[8] Ferguson J., et al. (2011), "Estimation Domestic US Airline Cost Of Delay Based On European Model", Journal of Transportation Research Part C, Vol. 33, hal. 311-323

[9] Hasan, (2002) Pokok-Pokok Materi Pengambilan Keputusan, Jakarta, Ghalia Indonesia.

[10] Horonjeff, R., and. McKelvey F. (2010). Planning \& Design of Airports, Fourth Edition, United States of America, McGraw-Hill, Inc

[11] Jungai T., \& Hongjun X. (2012) “Optimizing Arrival Flight Delay Scheduling Based on Simulated Annealing Algorithm", Journal of 2012 International Conference on Medical Physics and Biomedical Engineering, Vol. 33, hal. 348 - 353.

[12] Kelton, W.D., et al. (2003) Simulation With Arena, New York; McGraw-Hill

[13] Larasati, A. (2014), "Model Simulasi Diskrit Untuk Mengukur Efek Keterlambatan Jadwal Penerbangan Terhadap Antrian Pra Tinggal Landas Dan Pasca Pendaratan". Tugas Akhir, Jurusan Teknik Industri, Institut Teknologi Sepuluh Nopember.

[14] Pyrgiotis, N., Malone, K., \& Odoni, A. (2013). Modelling delay propagation within an airport network. Transportation Research Part C. Vol. 27, hal. 60-75.

[15] Ryerson M.S., et al. (2014). Time to burn: Flight delay, terminal efficiency, and fuel consumption in the National Airspace System. Journal of Transportation Research Part C. Vol. 69, hal. 286298.

[16] http://aeroengineering.co.id/

[17] http://www.ilmuterbang.com/

[18] http://www.rita.dot.gov/bts/help/aviation/html/under standing.html

[19] http://www.transtats.bts.gov/ot delay/ot delaycause $\underline{1 . a s p}$ 